\title{
Cultural Citizenship - some critical thoughts on the usefulness and potential risks of the concept*
}

\author{
Dr. Janny de Jong \\ University of Groningen
}

\begin{abstract}
Summary: I. Introduction.-II. Meanings and dimensions of citizenship.-III. Dimensions. - IV. European citizenship.-V. Cultural citizenship. - VI. Conclusion.
\end{abstract}

\begin{abstract}
Since the 1990s the idea of global, cosmopolitan, multicultural and cultural citizenship gained prominence. The notion of cultural citizenship originally suggested inclusiveness and diversity. It intended to recognise cultural rights of various groups in society, in other words multi-ethnicity and diversity. This inclusive notion has been challenged lately, and increasingly it also has been interpreted in the opposite way. The contradictory readings of this concept, for instance in various Member States of the European Union, question its usefulness. The focus on the cultural dimension of citizenship might even prove risky. Only a broad, "comprehensive" understanding of citizenship can reflect the interconnectedness and multiplicity of political, social and cultural ties between the citizen and the polity.
\end{abstract}

Keywords: Cultural citizenship, European identity, active citizenship.

Resumen: La idea de lo global, lo cosmopolita, lo multicultural y la ciudadanía cultural ha ido adquiriendo importancia desde 1990. En sus orígenes, la noción de ciudadanía cultural sugería inclusión y diversidad. Intentaba reconocer los derechos culturales de grupos sociales variados, en otras palabras, pluralismo étnico y diversidad. Recientemente, esta noción de inclusión se ha visto cuestionada, e incluso interpretada de forma contraria. La lectura contradictoria de este concepto, por ejemplo por parte de varios Estados miembros de la Unión Europea, cuestiona su utilidad. El énfasis en la dimensión cultural de la ciudadanía podría incluso resultar arriesgado. Sólo una amplia comprensión integradora de la ciudadanía puede reflejar la interconexión y multiplicidad de los vínculos político, social y cultural entre el ciudadano y el sistema político institucional.

Palabras clave: Ciudadanía cultural, identidad europea, ciudadanía activa .

* Recibido el 2 de noviembre de 2012, aceptado el 20 de diciembre de 2012. 


\section{Introduction}

Citizenship is very important, and a highly contested notion. When browsing through the great many books and articles that have been written about citizenship, particularly in the last three decades, it is astounding how many adjectives have been attached to the word citizenship; ranging from regional to global citizenship, social to cultural, inclusive and exclusive citizenship and every shade in between. This recent increase in citizenship studies does by no means imply that it is a "new" or contemporary notionlanguage, activities and institutions in the field of citizenship may even be called one of the most important, long lasting and ongoing struggles in the history of politics. ${ }^{1}$

Certainly the understanding of what citizenship means and represents has significantly altered through time, as well as the focus on specific aspects. "Citizenship and social class"- the seminal essay by the British sociologist T.H. Marshall published in 1950-would not be a very likely topic today if only because the Marxist concept "class" is not in vogue anymore. Titles such as Reframing Social Citizenship, on the other hand, immediately are recognised as current ${ }^{2}$. This particular title also shows, by the way, that Marshall's essay remained important. In fact it is noteworthy how very often it is quoted or referred to; tracing references to Marshall's essay in the Google scholar database renders a result of 6.678 direct quotes. ${ }^{3}$ The crucial importance of the notion citizenship was "rediscovered" in the late 1980s and early 1990s, and this also implied re-examining Marshall's distinction between three types of citizenship, legal, political and social. The enhanced interest in especially social citizenship in the 1980s was related to debates on the social welfare state and the "new" economic

1 TULLY, J., "Two meanings of global citizenship: modern and diverse," in PETERS, M.A., BLEE, H. and BRITTON, A. (eds.), Global Citizenship Education: Philosophy, Theoryand Pedagogy, Sense Publications, Rotterdam, 2008. Web http://www.southampton.ac.uk/smrn/ docs/tully_two_meanings.pdf, (Last retrieval 23/9/2012).

2 MARSHALL, T.H., "Citizenship and Social Class," in Sociology at the Crossroads, and Other Essays Heinemann, London, 1963, pp. 67-127. The essay was first delivered in the form of The Marshall Lectures in Cambridge 1949. TAYLOR-GOOBY, P., Reframing Social Citizenship, Oxford University Press, Oxford; New York, 2009.

${ }^{3}$ REES, A.M, "T.H. Marshall and the Progression of Citizenship," in BULMER, M. and REES, A.M. (eds.), Citizenship Today: The Contemporary Relevance of T. H. Marshall, UCL Press, London, 1996, pp. 1-24.; MARSHALL, T.H. and BOTTOMORE, T., Citizenship and Social Class, Pluto Press, London, 1992, p. 101.

http://scholar.google.nl/scholar?cites=14046845792627094931\&as_sdt=5\&sciodt $=0 \&$ hl=en, search (last retrieval on 19/7/ 2012); OERS, R. VAN, ERSBØLL, E. and KOSTAKOPOULOU, D., A Re-Definition of Belonging?, Extenza Turpin distributor, Biggleswade, 2010 , p. 338. 
policies such as Thatcherism and Reagonomics that were being introduced at that time.

Academic research into the matter of citizenship obviously reflects problems, debates and issues of the specific timeframe. It will not come as a surprise that citizenship often was-and is-put forward as a solution to current political or social issues. "Whatever the problem", political scientist Richard Bellamy writes with irony - "be it the decline in voting, increasing numbers of teenage pregnancies, or climate change-someone has canvassed the revitalization of citizenship as part of the solution" 4 . Revitalisation is the key word here: and this may also explain why so many adjectives have been invented in connection to citizenship in the first place: in order to show the difference with previous citizenship studies.

Since the 1990s it was the idea of global, cosmopolitan, multicultural and cultural citizenship that gained prominence. International and national and local developments related to migration, Europeanisation and globalisation and the end of the Cold War triggered this "cultural approach"5. With the growing interest for issues connected to multiethnic and multicultural societies, the topics of rights of ethnic minorities in multi-ethnical societies and democratic citizenship gained prominence as well. While especially the "liberal" view of citizenship had more or less overlooked how those with political and legal rights could exercise power over the vulnerable, these new strands offered a kind of redress. ${ }^{6}$ Political philosophers Will Kymlicka and Wayne Norman observed however, that minority rights and the so-called "democratic citizenship" often seemed an odd couple: "good" citizenship seemed to overlook specific practices of minorities, while appeals to minority rights were suspected of contradicting a "robust" conception of civic virtue ${ }^{7}$.

The concept of cultural citizenship reflects precisely that contradiction. The notion of cultural citizenship in connection with a global approach originally suggested inclusiveness and diversity. The aim was to recognise cultural rights of various groups in society, in other words multi-ethnicity

${ }^{4}$ BELLAMY, R., Citizenship: A very Short Introduction, Oxford University Press, Oxford, 2008, p. 1.

5 See for references to the concept of world citizenship in earlier periods, especially antiquity NUSSBAUM, M.C., "Cultivating Humanity," Liberal Education 84, no. 2, Spring 98, 1998, p. 38; NUSSBAUM, M., "Education and Democratic Citizenship: Capabilities and Quality Education," Journal of Human Development 7, no. 3, 11, 2006; BOWDEN, B., "The Perils of Global Citizenship," Citizenship Studies 7, no. 3, 2003, pp. 349-362.

${ }^{6}$ HOFFMAN, J., Citizenship beyond the state, Sage publications inc. London etc, 2004, Electronic reproduction. Palo Alto, Calif : ebrary, 2009, p. 9

7 KYMLICKA, W. and NORMAN, W., "Citizenship in Culturally Diverse Societies: Issues, Contexts, Concepts," in KYMLICKA, W. and NORMAN, W. (eds.), Citizenship in Diverse Societies, Oxford University Press, Oxford, 2000, p.1. 
and diversity ${ }^{8}$. Yet increasingly it also has been interpreted in the opposite way. In the exclusive reading of cultural citizenship, the concept is given an "ethnic twist". ${ }^{9}$ Obviously, these two interpretations rule each other out.

Because cultural citizenship is interpreted in so many contradictory ways, its meaning is diffuse at best. In this article the focus will not lay on the "contestedness" of the concept, however. The fact that a great variety of meanings exist is of course important, but what here is at stake, are also the practical implications of the concept in the context of the European Union (EU). Cultural citizenship was intended to build a more stable and cohesive society. That particular focus on culture however, might have drawbacks that question its very usefulness in this respect. To what extent is the application of cultural citizenship in the Member States of the EU a notion that, instead of expanding the possibilities to participate to all the different ethnic groups that live in a particular nation, is actually limiting these simply because of the focus on the cultural dimension? Firstly the various meanings and dimensions of citizenship will be briefly sketched. Then the introduction of European citizenship will be analysed, before turning to the different interpretations of cultural citizenship. Lastly a conclusion can be drawn about its usefulness and the potential risks involved.

\section{Meanings and dimensions of Citizenship}

In the simplest, narrowest definition citizenship is the legal relationship between the individual citizen and the polity. What this polity is, differed historically. In earlier times, for instance in antiquity, the polity in Europe was usually defined by the city. In the Netherlands in late medieval time, "burghers" belonged to the "civitas", the political community of the city. Interestingly though, in regions that were less urbanized such as the early modern PolishLithuania commonwealth, citizenship was a synonym for "nobility". ${ }^{10}$ In early

8 DELANTY, G., "Citizenship as a Learning Process: Disciplinary Citizenship Versus Cultural Citizenship," International Journal of Lifelong Education 22, no. 6, 2003, pp. 597-605, esp. p. 598; STEVENSON, N., "Cultural Citizenship in the 'Cultural' Society: A Cosmopolitan Approach," Citizenship Studies 7, no. 3, 2003, 331-348, esp. p. 345.

9 LÖFSTRÖM, J., "Historical Apologies as Acts of Symbolic Inclusion - and Exclusion? Reflections on Institutional Apologies as Politics of Cultural Citizenship," Citizenship Studies 15, no. 1, 2011, pp. 93-108, esp. p.104.

10 TILMANS, K., "The concept of the Dutch citizen," Resdescriptions.Yearbook of Political Thought and Conceptual History. 8, 2004, pp. 146-171, esp. pp. 146-147. http:// karintilmans.nl/pdf/citizenship.pdf, (last retrieval 10/10/2012); ELLIS, S. et alter, "Towards a citizenship of the European Union," in ISAACS, A.K. et alter (eds.), Perspectives on European Integration and European Union History. A Cliohworld reader, Pisa, 2011, pp. 45-72, esp. p. 59. 
modern and modern times the different patterns of state formation resulted in a variety of definitions of citizenship rights and concepts in Europe. This great variety is still in existence: it has even been called the "last bastion of sovereignty" in the European Union in that respect. ${ }^{11}$

For the modern reading of the concept citizenship the French revolution is of particular importance. Concepts like the "equality" of citizens and their political and social participation were put forward. One of the most famous documents in this respect is the French Declaration of civil rights and the citizen of 1789. It stressed the equality of the citizens before the law, and the sovereignty of the nation. Everyone who had the status of citizen - large segments of the population, for instance women, or the poor, were left out at that time-was supposed to participate in the nation. Therefore the French revolution "invented" national citizenship, historian Rogers Brubaker argued, because of features such as the introduction of civic equality with shared rights and obligations, the doctrine of national sovereignty and the direct connection between citizenship and nationhood. ${ }^{12}$ Paradoxically this republican notion of citizenship and nationhood emphasized universal rights, and made inclusion possible, but by stressing the unity of the nation also has entailed cultural assimilation.

Core elements in the concept citizenship are belonging (or membership)(1), rights (2) and participation (3). Depending on whether one uses a "thick" or a "thin" description, each of these concepts can mean different things. For instance membership or belonging can range from the legal, civic status, to cultural identity. ${ }^{13}$ The political, social and cultural ties between the citizen and the political communities are dynamic and subject to change. This holds also true for the rights and laws that are codified by means of a continuous democratic decision-making process. Rights and laws are closely related to the political culture; norms and values form an intrinsic part of it.

When citizenship is analysed in relation to the rule of law, it can be perceived as an opportunity: the rights that a citizen has and can execute. Rights also define the way participation takes place. A democracy does not function if a majority of the citizens abstain from political or civic action, such as voting. "Good citizenship" implies therefore active citizens. Citizens only feel the urge to participate however, if they not only are a

11 BRUBAKER, R., Citizenship and nationhood in France and Germany, Harvard University Press, Cambridge, MA, 1992, p. 180.

12 BRUBAKER, R.,Op.cit., Chapter 2.

13 BELLAMY, R., "Evaluating Union Citizenship: Belonging, Rights and Participation within the EU," Citizenship Studies 12, no. 6, 2008, pp. 597-611, esp. p. 599; see the table that Rainer Bauböck introduced in BAUBÖCK, R., Recombinant Citizenship, no. 67, Institute for Advanced Studies, Vienna, 1999, p. 4. 
member of the community and but also to some degree committed to it. "Rights" of course are not fixed in time but will change in response to altered circumstances and contexts. This means that the circle drawn in figure 1 has no fixed direction: rights may define the participation, but participation also influences the content of rights.

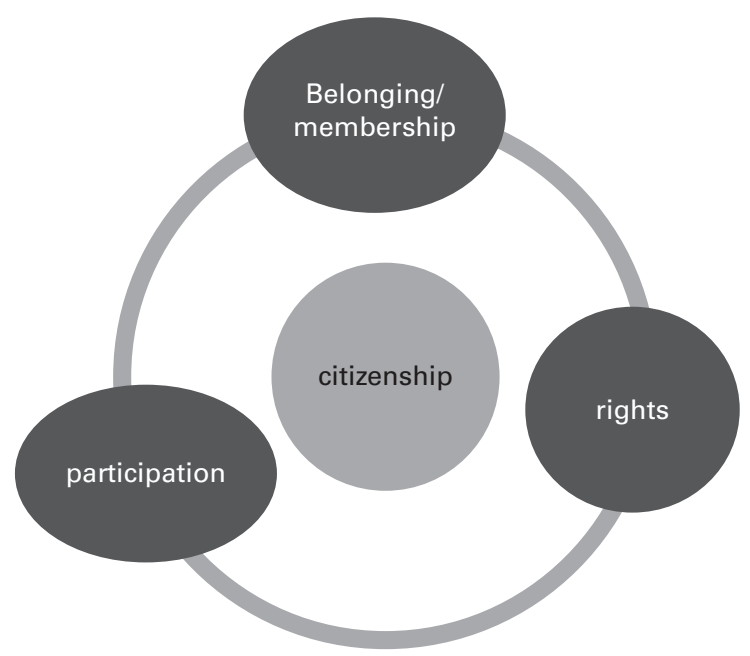

Figure 1

Core elements of citizenship

\section{Dimensions}

Citizenship can be divided into various civil, political and social dimensions or capacities. It was the already mentioned British sociologist T.S Marshall who in 1949/1950 was breaking new ground with the idea of social rights as welfare rights that were awarded on the basis of the status of citizenship, instead of some sort of charity to the poor and needy. Marshall sketched a linear development of citizenship rights through time; starting with civil rights, leading to political rights and ending with social ones. In other words, citizenship rights were becoming more encompassing through time, as the idea of the specific role of a democratic state developed. Marshall's ideas were highly influential, and innovative; before especially the social dimension had not been addressed in great detail. Still the influence of this rather short essay is remarkable given its limited scope-Marshal 
was only taking into account the English situation, taking furthermore the family, with a male breadwinner as the basic social unit.

In Marshall's time the inequality in society could be redressed to a certain extent by the state. Because of global influences, international organisations and increasing European integration that situation has become more complex. Citizenship furthermore became less and less tied to one national polity only, especially in the European Union that made free movement and settlement and employment possible in the early 1990s. The cultural diversity in most of the European states has increased both due to migration to the EU as to the enhanced possibilities of settlement and employment within the EU. Therefore Marshall's sequential development of civil, political and social rights has been further elaborated, to include for instance cultural rights. That is one of the reasons why cultural citizenship came in vogue.

The role of (im)migration is of crucial importance then for the current debate about citizenship. Worldwide the estimate of migrants living abroad is almost 214 million; in Europe only this number in 2010 was close to 70 million. ${ }^{14}$ The influx has in some countries led to a stricter policy, for instance with regard to the possibility of having two passports, or the introduction of so-called citizenship tests. In the last two decades the actual policy towards migrants in the EU has changed substantially. Due to the imposed restrictions on immigration, there no longer exists such a thing like "mass migration", though debates in (social) media and politics seem to suggest otherwise. ${ }^{15}$ However, it is also true that the real number of immigrants is difficult to decide, since by definition the number of unauthorised and illegal immigrants can only by an educated guess.

The problem of stateless people and refugees as such hardly is a new phenomenon of course. In 1950 for instance the office of the United Nations High Commissioner was established by the General Assembly of the UN to address the problem of the large number of people that were still uprooted since the Second World War. In 1951 political philosopher Hanna Arendt addressed the issue of refugees and asylum seekers from another, theoretical, perspective. In her book Totalitarianism she famously criticized the concept of inalienable human rights because the first half of the 20th

14 Dataset United Nation Populations division, http://esa.un.org/migration/p2k0data.asp. (last retrieval 14/9/2012). Based on United Nations, Department of Economic and Social Affairs, Population Division (2009). Trends in International Migrant Stock: The 2008 Revision (United Nations database, POP/DB/MIG/Stock/Rev.2008).

15 See for figures on migration worldwide: OECD Factbook 2011: Economic, Environmental and Social Statistics (Paris: Organisation for Economic Co-operation and Development, 2011), http://dx.doi.org/10.1787/888932502923 (last retrieval 10/1/2012). 
century had made clear that Rights of Man "proved to be unenforceable - even in countries whose constitutions were based upon them whenever people appeared who were no longer citizens of any sovereign state." 16 Minorities and stateless people in the 1930s and 1940s had lost their "right to have rights" and no place to turn to. ${ }^{17}$ The membership of a political community therefore was crucial for having rights. Arendt's observation is still valid for illegal migrants and to some extent to the refugees and asylum seekers today. It is what has been called calls the "perils" of global citizenship: being a citizen of the world is not a positive feat if there is no legally constituted authority to turn to in case of need for protection. ${ }^{18}$

This important matter was also stated by the report that the "Group of Eminent persons of the council of Europe" published in 2011 on the question on how to combine diversity and freedom in $21^{\text {st }}$ century Europe (2011). It pointed with concern to the policy in virtually all European states to control immigration, which in turn resulted in a substantial increase of illegal immigrants who are in fact "without the law" in the most literal sense. These people cannot invoke the protection of the law since the law consists the threat of deportation. Often asylum seekers enjoy very limited legal protection as well. ${ }^{19}$

In various countries in the EU the policy towards migrants and minorities became a matter for heated debate. Citizenship and citizen's rights developed into a highly precarious political area. Most of the European states introduced mandatory, test-based integration programmes, including sanctions for those who did not comply, ranging from fines, no family reunification to deportation. A clear relationship was suggested between integration and citizenship policies. ${ }^{20}$ Other issues arose in the Member States that joined the Union in 2004. Russians, for instance, found themselves stateless in the former Baltic States. ${ }^{21}$

While a lot of European Member States countries have adopted new citizenship laws, there is no convergence with regard to the content. The

16 ARENDT, H., The Origins of Totalitarianism, Meridian books, $2^{\text {nd }}$ enlarged edition 1958, New York, 1962, pp. 290-293

17 ARENDT, H., op. cit., pp. 296-297.

18 BOWDEN, op. cit.

${ }^{19}$ Living together. Combining Diversity and Freedom in $21^{\text {st }}$ century Europe Report of the Group of Eminent persons of the council of Europe, 2011, http://book.coe.int/ftp/3664. pdf, pp 20-22 (last retrieval 12/10/2012).

${ }^{20}$ KOSTAKOPOULOU, D., "Introduction", in OERS, R. VAN, ERSBØLL, E. and KOSTAKOPOULOU, D., A Re-Definition of Belonging?, Extenza Turpin distributor, Biggleswade, 2010, pp.1-24.

${ }_{21}$ BAUBÖCK, R., "Who are the citizens of Europe,"Eurozine, published 23 December 2006, web www.eurozine.com (last retrieval 15/9/2012). 
Member States have, however, worked towards creating a common European agenda since 1993 with regard to immigration and integration. In this respect the Communication on Immigration, Integration and Employment (2003) is relevant, since a " comprehensive" integration policy was called for. This implied next to socio-economic aspects, also cultural diversity, citizenship, participation and civil rights. Anti-racism and anti-discrimination were important elements in this approach ${ }^{22}$. The European Pact on Immigration and Asylum, that was submitted by the French Presidency and adopted in October 2008 by the European Council, seemingly adorsed this Communication. However, Doro Kostakopoulou, specialist in European Law and European Integration calls this in practice a retreat from pluralism, since the text explicitly referred to the "integration capabilities of migrants" 23 . The original version had included a compulsory integration contract that required migrants to conform to the national identity of the Member State.

The problem is of course that a strong stress on integration, or even assimilation, may conflict not only with the European Convention on Human Rights (1953), but also with the political criteria and democratic values that the European Council in Copenhagen had laid down as criteria for European Membership (1993). These criteria determined which states might join the European Union, which was established with the Treaty of Maastricht (1992). It was this treaty that also started a new phase of European citizenship in Western Europe.

\section{European Citizenship}

The treaty of Maastricht formally introduced European citizenship on top of national citizenship. The inclusion of European citizenship in the treaty was an important example of the pluralistic, inclusive, model of citizenship. The aim was to enhance and nurture feelings of belonging to Europe next to the national identity. This idea had been proposed before; in particular the ad-hoc Committee of the European Council on "A People's Europe" should be mentioned. As chair PietroAdonnino in 1985 had

${ }^{22}$ KOSTAKOPOULOU, D., op. cit, p. 13.

${ }^{23}$ KOSTAKOPOULOU, D., op. cit, p. 17. France does not recognise national minorities; it has signed nor ratified the Framework Convention for the Protection of National Minorities (FCNM). http://www.coe.int/t/dghl/monitoring/minorities/1_AtGlance/PDF_MapMinorities _bil.pdf (last retrieval 11/10/2012). Of the EU Member States Belgium, Greece, Island and Luxembourg have signed but not ratified FCNM. See also SASSE, G. and THIELEMANN, E., "A research Agenda for the Study of Migrants and Minorities in Europe," Journal of Common Market Studies (JCMS) 2005 vol 43 655-671, esp. p. 660. 
written the president of the European Council in the accompanying letter to the proposals of this committee: "It is essential to ensure for the citizen an active role as a participant in a Community which he understands and which offers real influence to him on matters of importance for his life". ${ }^{24}$ In a community that strived for a "Europe sans frontières", specific symbols were important to underline and strengthen this aim. A flag, anthem, emblem and a special Europe day were mentioned in that respect. In other words, these were all efforts to stimulate a common European identity and community ${ }^{25}$. The committee's proposals were adopted in Milano 1985.

Felipe González, former Spanish prime minister and member of the European Council, in retrospect explained the formal inclusion of European citizenship in the Treaty of Maastricht as a "proposal aimed at convincing Europe's men and women that what we were doing (in making the European Union) only made sense if we viewed Europe as belonging to its citizens. National identities and original citizenships would be compatible with this idea. We meant to add it as a bonus, as Europeans who shared a common project". ${ }^{26}$ González stressed that citizenship is not simply a legal status but also an identity that does not interfere with the national or regional identity. This last provision was even explicitly stated in the treaty of Amsterdam, $1997^{27}$.

From the outset then, the idea of European citizenship was closely connected to attempts at strengthening democratic legitimacy in the European Union, and increasing popular support for the EU. However, this positive idea was not very successful. Many citizens in Europe viewed attempts to create a European citizenship with suspicion; and, as the opinion polls of the Euro barometer shows again and again, the respondents' identification with the nation or region far exceeds than with Europe.

24 "A People's Europe. Reports from the ad hoc committee," Bulletin of the European Communities Supplement 7/85, quote on p. 7. http://aei.pitt.edu/992/1/andonnino_report _peoples_europe.pdf, (last retrieval 27/9/2012).

${ }^{25}$ See for a critical view on the importance of these symbols to create a "politics of emotion", PAPAGAROUFALI, E., "Of Euro-symbols and Euro-Sentiments: The case of Town and School Twinning," Historein 8, 2008, pp. 72-82, esp. 73. http://www.nnet.gr/ historein/historeinfiles/histvolumes/hist08/historein8-papagaroufali.pdf, (last retrieval 111/10/2012).

26 GONZÁlEZ, F., "European Union and Globalization," Foreign Policy, No. 115, Summer, 1999, pp. 28-37, esp. p. 30. Jstor. (last retrieval: 14/06/2012). SHORE, C., Building Europe: the Cultural Politics of European Integration, Routledge London, 2000, pp. 74-75; SHORE, C., "Whither European Citizenship? Eros and Civilization revisited," European Journal of Social Theory 7, no.1, 2004, pp. 27-44, esp. pp. 30-31.

27 PREUSS, U.K. et alter, "Traditions of Citizenship in the European Union," Citizenship Studies, 7, no. 1, 2003 pp. 3-14. 
This illustrates also how very much the three earlier defined core elements in citizenship-belonging, rights and participation-must be considered as a whole. Attempts a creating a feeling of belonging through simply proclaiming citizenship backfires.

Voting has been called crucial to the act of citizenship in democracies. "No act of citizenship, and no form of participation, is more important in a democracy than that of voting". ${ }^{28}$ Yet in order to take the trouble to vote, there also needs to be an urge for civic participation, and the idea that the vote makes a difference. In that respect the turnout at elections for the European Parliament does not render a positive image; it is rather low and gradually decreasing. (See figure 2). The question "where should we invest our money", that was used in the last election campaign for the European parliament (2009), was highly relevant. But it did not convince. Many European citizens did not consider it worth taking the trouble to take part in the election process. The average turnout was only $43 \%$.

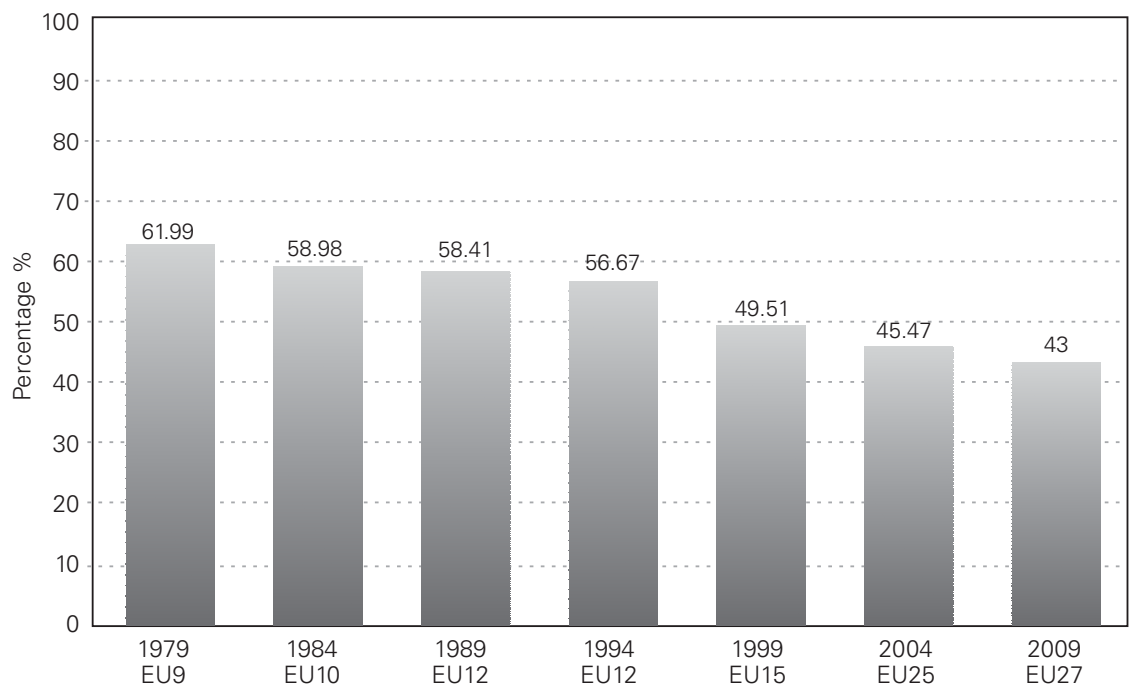

Figure 2

Turnout at the European elections (1979-2009)

Source: http://www.europarl.europa.eu/aboutparliament/en/000cdcd9d4/Turnout-\%281979 $-2009 \% 29 . \mathrm{html}$

${ }^{28}$ KIDD, Q., Civic Participation in America, Pallgrave, Macmillan, Houndmills, Basingstoke, New York, 2011, p. 13. 
However, because the European Parliament (EP) is not a sovereign legislative body-European citizens can only in a very limited sense use democratic rights usually related to citizenship - the turnout necessarily only to a limited degree can serve as a measuring rod. The EP only to a limited degree serves as a "real" parliament; there is no government that the members of parliament can send home. What is not helpful either to attract interest, is the fact that the elected are member of national parties that in the EP usually cooperate in transnational groups. Therefore parties that at a national level may compete, cooperate closely at transnational, European level, in most cases in "Europarties"29. Yet, the Members of the EP are seldom elected because of their salient capacities in European politics; national issues play the upper role here as well. It makes politics at the EP not easy to gasp.

The most powerful impact of European citizenship, anyhow, is therefore not the franchise to the European parliament but the earlier mentioned creation of a common space of free movement and settlement. One might very much question however, whether this particular provision created a sense of togetherness, and/or belonging and whether it stimulated the idea of a common European identity.

Of course European integration has stimulated jobs and employment, and created a dynamic society with a lot of social interaction at various levels. The number of people that travel across borders, and live, work or study abroad has risen enormously. One of the major problems is however, that patterns of shared culture and interaction tend to follow social class-lines. Those who feel European and favour the European integration process are usually found in the middle and upper middle classes; and do not hold conservative nationalistic political views. They also tend to be relatively young ${ }^{30}$.

The free movement and settlement has also stimulated Eurosceptic feelings. The fear of an influx of cheap labour from the new EU countries did not strengthen the idea of a common European identity and citizenship. The fact that in 2004 no less than 12 of the member states opted for restrictions on the opening of their labour markets to citizens of the new member states was an important, negative, signal. ${ }^{31}$

29 See for a list of the grants 2004-2012 http://www.europarl.europa.eu/pdf/grants/grant _amounts_parties_01-03-2012.pdf, (last retrieval 25/09/2012).

${ }^{30}$ FLIGSTEIN, N., Euroclash: The EU, European Identity, and the Future of Europe: The EU, European Identity, and the Future of Europe, Oxford University Press, Oxford, etc., 2008, pp. 136-139;"Future of Europe , Standard Eurobarometer 71/spring 2009, pp. 34-37. http://ec.europa.eu/public_opinion/archives/eb/eb71/eb713_future_europe.pdf, (last retrieval, 11/10/2012).

31 BAUBÖCK, R., "Who are the citizens of Europe," Eurozine, published 23 December 2006, web www.eurozine.com, (last retrieval 15/9/2012). 
The introduction of the idea of European citizenship in the 1990s had meant to foster both the regional and national identity, and the feeling of belonging to a larger community. A comparable project, this time by the Council of Europe, was the Education for Democratic Citizenship (EDC). It started in 1997 and aimed at identifying values and skills that citizens needed to become a "participating citizen", subsequently how these skills were acquired and could be disseminated. May 1999, at its 50th anniversary, the Committee of Ministers of the Council of Europe agreed upon a Declaration "For a greater Europe without dividing lines" that contained an Appendix devoted to a Declaration and Programme of Education for Democratic Citizenship. The idea was that if citizens obtained knowledge about the institutions and practices of democracy, and learned how to exercise influence at various levels, they could also deal with the difference "knowledgeably, sensibly, tolerantly and morally". This would strengthen mutual understanding, as well as social cohesion. Democratic and active citizenship were mentioned in one breath. ${ }^{32}$

A current project, subsidized and stimulated by the European Commission is the Europe for Citizensprogramme. An earlier edition had been called Europe of citizens. It started inin 2007, with a total budget 215 million Euros, and will conclude in 2013 with the European Year of Citizens. Ranging from town twinning meetings to remembrance projects, this programme's intention is to develop mutual understanding and a sense of European identity by personally involving European citizens. The keyword in this programme is "active citizenship". ${ }^{33}$ At European institutional level citizenship is considered of crucial importance. A future programme 20142020 will focus on civic participation. ${ }^{34}$

Yet in recent time the EU has also taken a step backwards. The negative outcomes of the referenda on ratifying the Treaty establishing a constitution for Europe (TCE) of 2004 in France and the Netherlands in May-June 2005, showed that at least the voters that said "NO" still had to be convinced of the merits of further integration. While the TCE had included a reference to

32 Council of Europe. Committe of Ministers, The Budapest Declaration For a greater Europe without Dividing Lines, 7 May 1999. WEB; https://wcd.coe.int/ViewDoc.jsp?id =448149\&Site=CM, (last retrieval 27/9/ 2012); see also STARKEY, H., "Democratic Citizenship, Languages, Diversity and Human Rights. Guide for the development of Language Education Policies in Europe From Linguistic Diversity to Plurilingual Education". Reference Study http://www.coe.int/t/dg4/linguistic/Source/StarkeyEN.pdf, (last retrieval, 26/9/2012).

$33 \mathrm{http} / / /$ eacea.ec.europa.eu/citizenship/programme/about_citizenship_en.php (last retrieval 11/10/2012).

${ }^{34} \mathrm{http}$ ://ec.europa.eu/citizenship/about-the-europe-for-citizens-programme/future -programme-2014-2020/index_en.htm, (last retrieval 11/10/2012). The new budget is 229 million Euro. 
EU symbols such as the flag, and the anthem, any state-like Union symbols, as well as terms such as constitution and foreign minister were omitted in the treaty of Lisbon (2007) that came in place for the TCE. The Euro was the only exception. ${ }^{35}$ Leaving out the symbols that referred to nationstates was a kind of lip-service to those who feared a European super state or a European citizenship coming instead of nationally defined one. This may give a clue about the prospects of cultural citizenship that has been promoted in lieu of nationally defined citizenship.

\section{Cultural citizenship}

The notion of cultural citizenship is very much related to research and debates on multiculturalism, globalisation, integration and assimilation. Academics such as sociologist Gerard Delanty for instance, stress the role of citizen as an active agent. Citizenship is not confined to the territorial limits of a given state anymore; it is multi-leveled. Because the nationstate has become less "sovereign" due to processes such as globalisation of markets, communication and European integration, he argues that the nation-state, though still powerful, no longer can provide the framework for citizenship in all its aspects. His conclusion is that citizenship reflects "the pluralism of contemporary culture and the fact that there is no single national culture but contested sites of belonging" 36 .

Cultural citizenship has also been interpreted as a specific cultural policy to build upon coherence and stability in society. In 2007 the Dutch advisory body Council for Culture for example specifically mentioned the notion of cultural citizenship in its report Innovate, Participate! Culture, it stated, was the glue that keeps citizens together, much more than for instance than public authorities were able to do, and cohesion was particularly important in a time in which forces like migration, globalisation had made the society more diverse. The Dutch official policy towards arts, heritage and media should stimulate and enable citizens to make the "proper" decisions. In other words cultural policy with an open eye and mind for differences in society would encourage the acceptance of diversity in the country with it all its ethnic and cultural differences and

35 The Treaty of Lisbon, http://www.europarl.europa.eu/ftu/pdf/en/FTU_1.1.5.pdf; See OFFICIAL JOURNAL OF THE EUROPEAN UNION, Treaty establishing a Constitution for Europe, 16-12-2004, pp. C310/13. http://eur-lex.europa.eu/LexUriServ/LexUriServ.do?uri $=\mathrm{OJ}: \mathrm{C}: 2004: 310: 0011: 0040: \mathrm{EN}: \mathrm{PDF}$, (last retrieval 11/10/2012).

${ }^{36}$ DELANTY, G., The Cosmopolitan Imagination, the renewal of Critical Social Theory, Cambridge, University Press, Cambridge, 111-131, quote on p. 125. 
varieties. ${ }^{37}$ The report clearly distanced itself from a xenophobic and closed community approach that, as was stated on the very first page of the report, did not fit in the Dutch tradition of cosmopolitanism, enterprise, tolerance, democracy, freedom and innovation. Culturally citizens are not limited to national borders, but consumers of what was called "worldwide cultural heritage". Arts, cultural practices and cultural institutions were important means to develop a "national political community in a global context". ${ }^{38}$

In the meantime this report did not signify a clear difference with the cultural policy that was already in place: it fitted neatly in the concrete actions that the then incumbent State Secretary had proposed in June 2006 to promote diversity, for instance in the Programme for Cultural Dialogue. ${ }^{39}$

However, at the same time another interpretation of cultural citizenship was clearly visible as well, also in the Netherlands. In contrast to the aforementioned inclusive models of cultural citizenship, it is another interpretation that stresses the role of education in turning newcomers such as immigrants to "proper" citizens. In fact that model is increasingly taken: the common tendency in Europe in general is to equate incorporation ofindividual migrantson equal terms in the core institutions of society,with the necessity of the acquisition of "cultural competences". ${ }^{40}$ Which cultural competences exactly, and to what degree, are not answered in the same way in the various European Member States. The ultimate form are the citizenship tests that ideally constitute a bridge to the culture, responsibilities, privileges and values of their new country. The tendency then within European national states is towards a more instead of a less nationally defined citizenship. In citizenships tests for prospective citizens that have been installed in countries such as Great Britain, Germany and the Netherlands, values play a distinctive role. New citizens are not only asked about their knowledge of the language and law and order, but also should be able to show whether they are able to understand way of living in their prospective country. ${ }^{41}$

${ }^{37}$ RAAD VOOR CULTUUR, Innoveren, Participeren! Advies Agenda Cultuurbeleid en CultureleBasisinfrastructuur. Den Haag, 2007.

38 RAAD VOOR CULTUUR, op. cit., p. 13, See also BOOMKENS, R., "Cultural citizenship and real politics: the Dutch case," Citizenship Studies14, No. 3, 2010, pp. 307-316, esp. p. 313.

39 MINISTRY OF EDUCATION, CULTURE AND SCIENCE, Cultural Policy in the Netherlands, edition 2009, Ministry of Education, Culture and Science/Boekmanstudies, The Hague, Amsterdam 2009, p. 58.

40 Integration and Integration policies. IMISCOE Network Feasibility Study, University of Bamberg, 2006.http://www.efms.uni-bamberg.de/pdf/INTPOL\%20Final\%20Paper.pdf. Last retrieval, $11 / 10 / 2012$.

41 JONG, J. DE, “'Here we go again'. The Supposed Failure of Multiculturalism in Historical Perspective," in TAMCKE, M., JONG, J. DE, KLEIN, L. and WAAL, M. VAN DER (eds.), Europe - Space for Transcultural Existence Volume 1 in the Series "Studies in Euroculture", Universitätsverlag Göttingen, 2012, pp. 116-128. 
This reading of cultural citizenship is closely related to a more critical stance in the public domain on the multicultural society. This in its turn has different causes. Often the terrorist attacks of $9 / 11$ and subsequent terrorist activities in Madrid and London are put forward as crucial in changing the mindset to more critical views. In the Netherlands the murder of a right wing populist politician and a polemic filmmaker-both notorious for their criticism on Islam-definitely played an important role in the hardening of the tone of the national debate on the multicultural society. The 2005 "banlieue" riots in Paris were put forward in the public debate as proof for the failure of the French model of integration. In popular discourse the term banlieue, which simply means suburb, quickly became shorthand for the discussion of the role of ethnic minorities and Islam in France. The paradox was that when Islam leaders were trying to calm down the riots, they failed because the rioters did not associate with Islam, yet precisely because these Islam leaders took this responsibility; this reinforced the image of the riots as "an Islam problem", while in fact social economic conditions played an important role. ${ }^{42}$ A study in 2009 demonstrated ethnic profiling in stops and identity checks by the police in Paris.Especially young members of ethnic minorities were subject to police checks because of their physical appearance and style of clothing, not because of their behaviour. ${ }^{43}$

In November 2009 an official national debate started in France, initiated and monitored by the ministry of National Identity, Integration and Immigration. It had the aim to collect views of the public about what

42 GREWAL, K., "The Threat from Within' - Representations of the Banlieue in French Popular Discourse," in KILLINGSWORTH, M. (ed.), Europe: New Voices, New Perspectives: Proceedings From The ContemporaryEurope Research Centre Postgraduate Conference, 2005/2006 (Melbourne: The Contemporary Europe Research Centre, The University of Melbourne, 2007), pp. 41-67, quote on p. 47.

http://cerc.unimelb.edu.au/publications/Europe\%20new\%20voices\%20ch3.pdf. Last retrieval 28 Sep. 12. EL-TAYEB, F., “The Birth of a European Public': Migration, Postnationality, and Race in the Uniting of Europe", American Quarterly, 60, 2008, pp. 649-670.

In the meantime the riots and looting that took place in suburbs of London in August 2011 and some days later in cities such as Liverpool and Manchester showed that riots, looting and heavy violence certainly are not the prerogative of ethnic minorities. Where social economic deprivation may have been of importance in England, very recent heavy fighting and looting between youth and the police in a quiet town of Haren, the Netherlands, after a facebook invitation for a birthday party went viral, showed many influences, such as the role of social media, copy-cat behaviour after a popular film ('Project X), 'hooliganism', as well as boredom, but no deprivation of any kind.

43 OPEN SOCIETY FOUNDATIONS, Profiling Minorities: A Study of Stop-and-Search Practices in Paris, 2009, p. 10 URL: http://www.soros.org/sites/default/files/search_20090630. Web.pdf last retrieval 10 October 2012. PATRICK, S., French National Identity and Integration: Who Belongs to the National Community? Washington, DC: Migration Policy Institute 2012, p. 16. 
constituted French values and patriotism. It seemed as if the issue was how to define a "good Frenchman" and a good citizen. The official website of this debate went haywire at once and proved a format for extreme-right utterances. This debate proved to be highly divisive and was stopped after a few months. ${ }^{44}$

This example shows that a particular focus on culture and identity is risky. In the concept citizenship one might argue that this emphasis has little practical added value. Cultural particularities and characteristics are already embodied in the laws of the country. Culture, values, and identity are embedded in the three key dimensions of citizenship: membership/ belonging, rights and participation. Furthermore it is important to make a clear and proper distinction between civic rights and identity. A newcomer to a country obviously should respect the laws, but that does not imply that all values should be adopted as well. As philosopher TzvetanTodorov remarked in The Fear of Barbarians "Only totalitarian states make the love of one's country obligatory". ${ }^{45}$

\section{Conclusion}

Citizenship is a very important concept both in a national and European context. Only a broad, "comprehensive" understanding of citizenship can reflect the interconnectedness and multiplicity of political, social and cultural ties between the citizen and the polity. Legal, political, social 'and cultural rights and obligations are all part of contemporary citizenship.

Citizenship should not be conflated with (national) identity issues. In Europe, that is multi-ethnic and multi-cultural by definition, issues related to national identity have proven to be issues that arouse passions very quickly and tend to be very divisive.

To lay the stress on the cultural dimension in the concept citizenship is no problem provided that this does not limit the rights and obligations of citizenship to the cultural field only. Terms that define action or participation, like "active citizenship" however, are less sensitive and therefore more useful than the idea of cultural citizenship. While active citizenship defines what someone does with his or her rights and obligations, how to put it into practice, cultural citizenship can best be understood as a dimension of citizenship.

${ }^{44}$ MOERLAND, R., "French Identity debate is getting out of control", 22-12-2009, NRC. $N L$ International edition. Website archive.http://vorige.nrc.nl/international/article2443227 .ece/French_identity_debate_is_getting_out_of_control. Last retrieved 5/10/2012.

45 TODOROV, T., The Fear of Barbarians:Beyond the Clash of Civilizations, translated from the French by BROWN, A., Polity Press, Cambridge, 2010, pp. 80-81. 
It is like sociologist Ralf Dahrendorf wrote "A civilised society is one in which common citizenship rightscombine easilywith differences in race, religion or culture. It is also one that does not useits civic statusas a weapon for exclusion". ${ }^{46}$ Citizenship today no long reflects upon sovereign, closed and homogeneous political communities - if indeed it ever deed. Certainly European citizenship does not. Citizenship reflects diversity.

46 DAHRENDORF, R., "Citizenship and social class," in BULMER, M. and REES, A.M. (eds.), Citizenship today. The contemporary relevance of T.H. Marshall UCL Press, London and Bristol 1996, pp. 25-48, quote on p. 32. 